[2] "Sposib avtomatichno kerovanogo podribnennya makuhi oliynih kultur ta pristriy dlya yogo zdiysnennya", UA 77864, 2007.

[3] "Sposib avtomatichno kerovanoyi termoobrobki zerna", UA 89433, 2009.

[4] "Sposib avtomatichno kerovanogo sushinnya nasinnya", UA 113670, 2017.

[5] "Avtomatichna susharka nasinnya", UA 115077, 2017.

[6] DSTU 4811:2007, "Nasinnya oliynih kultur: Metodi viznachennya vologosti", Standart Derzhspozhivstandart Ukrayini, Kiyiv, 2008.

[7] OST 10 108-88, "Semena vinogradnyie dlya promyishlennoy pererabotki: Tehnicheskie usloviya", Ministerstvo selskogo hozyaystva, Moskva, 1988.

[8] SOU 15.3-37-091:2004, "Poroshok z makuhi nasInnya vinogradu: Tehnichni umovi", Minagropolitiki Ukrayini, Kiyiv, 2004.

UDC 18:011.56:502.33

\title{
FEATURES OF THE TECHNICAL OBJECTS CONTROL WITH REGISTRATION THEIR WEAR-OUT
}

\author{
Voinova S.A. \\ Odessa National Academy of Food Technologies, Odessa \\ ORCID: 0000-0003-0203-0599 \\ E-mail: voinova_s@yahoo.com
}

Copyright (C) 2018 by author and the journal "Automation technologies and business - processes. This work is licensed under the Creative Commons Attribution International License (CC BY). http://creativecommons.org/licanses/by/4.0

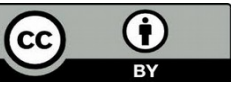

ONAFT

Open Access

DOI: $10.15673 /$ atbp.v10i4.1228

\begin{abstract}
The operation of technical objects is subject to the regulatory conditions established by their manufacturer. Regime of regulatory conditions keeping needs to be controlled. A new technical object at the time of commissioning has an initial, maximum level of technological efficiency of operation, including ecological, economic and general technical components, and has an initial, complete working capacity resource too. During operation, the technical object wears-out, its technological efficiency is reduced. In accordance with the international standard and the standard of Ukraine, a technical object that has exhausted a resource is subject to decommissioning and replacement with a new technical object, since at a level of technological efficiency that is less than the minimum, the use of technical object is inexpedient. However, in the current difficult economic conditions in Ukraine, the replacement of worn-out equipment with a new one is impracticable. Further use of worn-out equipment is inevitable. To control a worn out object, complex automation is required. The technical object is studied in this direction from three positions. The first is to study the process of wearing-out. The second is the prediction of wearing-out dynamics. The third is the object control in the process of its wearing-out. The development of the theory and practice of worn out objects automating leads to the formulation of new tasks. With long-term operation of the equipment, it is necessary to periodically adjust its characteristics. It is necessary to create adaptive automatic control systems that take into account the degree of equipment wear-out and conditions of its operation. It is important to establish the patterns of influence of the current state of the equipment and the operating conditions on its residual resource. A productive way to increase the efficiency of worn-out equipment is its renovation by implementing measures that increase the level of efficiency of the most worn-out elements of technical objects. The technical objects control with registration their wear-out will ensure compliance with the regulations for their operation.
\end{abstract}

Keywords: technical object, regulatory conditions, wear-out, control, technological efficiency, automation, renovation.

\section{Introduction}

The stagnant development of world production, which began in the middle of the last century and continues today, has led to a complication of its state. In Ukraine, as in other countries, in the fleet of operating equipment, the proportion of technical objects (TO) that have spent their working capacity resources has increased prohibitively. For example, in the most advanced 
industry - power engineering - more than 95\% of the existing boiler equipment has worked more than 1.5-2.5 resources. The level of technological efficiency of worn-out equipment is lower, the longer it functions after the completion of its resource use. Such equipment needs to be renovated in order to improve its technological efficiency. The next, higher level of renovating a technical object is the renovating of the control system of a technical object with regard to its wear-out.

The problem of increasing the technological efficiency of worn-out equipment has been formed and continues to worsen. The significance and scope of the required varied efforts to solve the problem are of the state level and of paramount importance. The program of measures to solve the problem is complex, very resource-intensive and urgent.

The most important condition for successfully solving this set of problems is to ensure high-quality control of all stages and parts of the process of solving it.

One of the elements of the problem is the task of technical objects control with registration their wear-out.

A new TO at the time of commissioning has an initial, maximum level of technological efficiency of operation, including ecological, economic and general technical components, and has an initial, complete working capacity resource too. In practice, the level of technological efficiency of TO is judged by the level of one of the three components listed above, which is accepted as the leading one for this TO.

From the moment of putting into operation, TO begins the expenditure of a resource, wears out. This leads to a continuous decrease in the level of its technological efficiency, all its components. In this case, the residual working capacity resource is reduced.

At the moment of the completion of the expending (i.e. exhaustion) of the resource, the TO reaches its limit state, the level of its technological efficiency reaches its minimum permissible value.

In accordance with the international standard and the standard of Ukraine, a TO that has exhausted a resource is subject to decommissioning and replacement with a new TO, since at a level of technological efficiency that is less than the minimum, the use of TO is inexpedient, if to proceed on generally accepted standards and requirements for the degree of perfection of relevant existing TO.

The TO working capacity resource, declared by its manufacturer, can be realized if the regulatory conditions of operation specified by the manufacturer are observed. Regulatory conditions are a complex set of interrelated technical and organizational factors. To comply with the regulatory conditions, the maintenance regime for this complex must be controlled. This control task is very difficult. In particular, due to the need to renovate the traditional control process, taking into account wear-out.

As it's known, the operated technical object wears-out. The level of its technological efficiency decreases. The patterns of this process are complex and insufficiently studied. This set of questions is the subject of technical gerontology (TG).

\section{Statement of problem}

The solution of the TG problems is based on the optimization of the operating mode of TO, which can be implemented only through the use of their integrated automation. At the same time, it is necessary to use the entire arsenal of automation equipment, all its elements, and above all, control, regulation, blocking, protection, alarms, and technical diagnostics.

It is assumed that the TO is initially equipped with traditional means of automation, which help to solve common technological problems. Realignment to automation in accordance with the rules and regulations of the TG puts forward new elements of technological problems, sometimes requiring an unconventional approach to finding ways and means to solve them. It puts forward new tasks within each of the three functions of the TG as a scientific discipline [1 - 4].

\section{Solutions of problem}

Let us dwell on the functions of the TG.

1. The TO studying with registration their continuous wear-out (primarily due to the degradation of structural materials by strength properties) during operation.

2. Prediction (forecasting) of the process of wear-out of objects in time.

3. Object control taking into account the process of their wear-out in time, which is equivalent to the indirect control of this process.

Within the framework of the first function, it is necessary to study in depth a number of issues, including the following:

- factors affecting the condition of the TO; means of obtaining signals proportional to the current level of physical quantities, which act as such factors;

- the separation of these factors into the ones which depend on the properties of TO and the regime factors which do not depend;

- mechanism, character, direction, intensity of the impact of these factors (static characteristics);

- the consequences of their long-term effects on TO, i.e. signs of wear-out (dynamic characteristics of output parameters, first of all - strength and other service properties of structural materials in technologically especially important details, properties of the surface layer on their working surfaces, deformation of gaps in joints, regime of appearance and development of cracks, etc.);

- the dynamics of change in the state of TO (its reaction) under the action of various factors individually and in their totality; 
- methodology and method for assessing this state based on the analysis of data about its reflecting parameters, characteristics of TO;

- indicators (characteristics) of the properties and state of important parts and TO as a whole, the level of which should be affected by the automatic control system (ACS) in the framework of solving the general task of control of TO wear-out ; means of receiving signals proportional to the current level of such indicators;

- technological process parameters that characterize the mode of TO operation, the value of which can be used in automation to solve this problem; means of receiving signals which proportional to the current level of these parameters.

In the second function, the following is necessary:

- to have information about the properties, TO state and mode of operation at the previous stage;

- to have the results of solving the problems of the first function;

- to have information about the permissible deviations of the controlled parameters of the TO state (for example, about the permissible degree of degradation of structural materials by strength parameters) and the technological process at the upcoming stage of their operation;

- to have a technical assignment for the projected phase of the TO operation, which contains information about the upcoming mode of operation and the allowable degree of wear;

- to perform the estimated forecast of TO wear-out and tear at the upcoming stage of their operation;

- to develop organizational-technical regulation for the TO control at the upcoming stage of their work.

As part of the third function, the following is necessary:

- to ensure the collection of current operational information about the TO state and the state of the technological process, their processing, generalisation and analysis;

- based on the current results of the analysis, promptly to diagnose the state of the TO in real time (or with an admissible small delay);

- on the basis of the obtained data, to work out an the control algorithm for the process of wear-out and tear for the next period;

- to ensure the operation of the ACS of process TO wear-out in accordance with the regulations drawn up according to the norms of the TG;

- to carry out the necessary scientific procuring and technical service of ACS of wear-out process.

It should be noted that the evolution of TG puts forward a number of new technological tasks within each of the three above mentioned functions. In this regard, in relation to the field of this scientific discipline before the theory and practice of automation, features of solving traditional problems appear, new problems arise. Among the latter are the following:

- identification of objective unambiguous clear signs of TO wear-out, free from the influence of any factors except its condition;

- the transformation of these signs into a useful technologically expedient signal of full value metrologically , changing its parameters and transferring it to the automation system;

- creation and development inside the existing systems of technical diagnostics of the element (unit) responsible for assessing the condition (degree of wear-out) of TO, taking into account their operating time (age);

- creation in the automation system of a contour of software control of the TO wear-out process, containing elements of logic and designed to extremely slow down this process, to ensure a high degree of adaptation of TO to operation conditions, to assess their condition, to optimize the operation mode taking into account the degree of wear-out, to evaluate the residual working capacity resource.

Traditional ACS are customized with regard to the actual static and dynamic characteristics of TO in controlled areas of the technological process. Over time, due to the wear-out of objects, these characteristics undergo changes. Therefore, for equipment used for a long time, it is necessary periodically to do testing and adjust the characteristics. This is one of the elements of novelty in the application of traditional automation.

The radical solution of the problem is to create such ACSs of TP that would allow to optimize the process of control of objects taking into account their continuously changing state throughout their operation. This solution should be based on the use of special adaptive self-adjusting ACS in which the adaptation node operates according to an algorithm that takes into account the current state (degree of wear-out) of the TO and the conditions of their operation.

The wear-out control program should primarily concern the most vulnerable parts of TO, i.e. those that determine their condition throughout the campaign. In practical conditions, the adjustment of the program or its individual fragments is inevitable. In particular, after the reconstructive repair of the mentioned vulnerable parts of TO, it is necessary to make corrections in the appropriate places of the program. In this sense, the adaptability of the wear-out management program must be high.

To create new ACS by the TO wear-out process, to develop new algorithms, it is necessary to know the regularity of the influence of the current state of TO, conditions and duration of operation on the properties and residual resource of these objects. Data collection to establish these regularities is an important and urgent scientific and technical problem. It has significant features in each of the areas of production, in each of the real TO.

It is essential to reflect the tasks of the TG in the curricula of universities [5]. 
http://www.atbp.onaft.edu.ua/

\section{Conclusions}

1. The operation of technical objects is subject to the regulatory conditions established by their manufacturer.

2. Regime of regulatory conditions keeping needs to be controlled.

3. During operation, the technical object wears-out, its technological efficiency is reduced.

4. To control a worn out object, complex automation is required.

5. A worn-out technical object is studied from the standpoint of studying the process of wearing-out, predicting the dynamics of wear-out, and controlling the object in the process of its wear-out.

6. With long-term operation of the equipment, it is necessary to periodically adjust its characteristics.

7. It is necessary to create adaptive automatic control systems that take into account the degree of equipment wear-out and conditions of its operation.

8. It is important to establish the patterns of influence of the current state of the equipment and the operating conditions on its residual resource.

9. Control of technical objects with regard to their wear-out ensures compliance with the regulations for their operation.

10. A productive way to increase the efficiency of worn-out equipment is its renovation by implementing measures that increase the level of efficiency of the most worn-out elements of technical objects.

11. The technical objects control with registration their wear-out will ensure compliance with the regulations for their operation.

\section{References}

[1] Voinova S.O. Tehnichna gerontologiya yak naukova distsiplina. Zmist. Mistse. Priznachennya / Mater. n.-t. konf. «Novyie i netraditsionnyie tehnologii v resurso- i energosberezhenii», 28-29 sent. 2006g., Odessa - Kiev: ATM Ukrainyi, 2006.- S. 16 - 20.

[2] Voinova S.O. Tehnichna gerontologiya i yakist roboti znoshenogo ustatkuvannya / Mater. VI Mezhdunar. n. - praktich. konf «Kachestvo, standartizatsiya, kontrol: teoriya i praktika», 26-28 sent. 2006g., Yalta. - Kiev: ATM Ukrainyi, 2006. - S.14 - 16.

[3] Voinova S.A. Tehnicheskaya gerontologiya. Potentsial vliyaniya na effektivnost funktsionirovaniya tehnicheskih ob'ektov / Mater. za VI Mezhdunarodna nauchna praktichna konferentsiya «Naynovite postizheniya na evropeyskata nauka-2010», 17 - 25 yuni, 2010g. Tom 20 «Tehnologii. Fizicheska kultura i sport».- Sofiya: «Byal GRAD-BG» OOD, 2010.- S. 79 - 84.

[4] Voinova S.O. Upravlinnya tehnichnimi ob’ektami i tehnichna gerontologiya / Schokvartalniy nauk.-virobn. zhurnal «Avtomatizatsiya tehnologichnih i biznes-protsesiv», 2011, № 7, 8.- Odesa: ONAHT, 2011.- S. 20 - 23.

[5] Voinova S.A. Mesto tehnicheskoy gerontologii v spetsialnyih distsiplinah tehnicheskogo vuza / Zb. tez. dopov. 32-yi nauk. - metod. konf. vikladachiv ODAHT "Problemi metodichnogo zabezpechennya bagatostupenevoyi vischoyi osviti”, Odesa, 10-12 kvitnya 2001r. - Odesa: Minosviti Ukrayini, 2001. - S. 46.

\section{Список использованных источников}

[1] Воінова С.О. Технічна геронтологія як наукова дисципліна. Зміст. Місце. Призначення / Матер. н.-т. конф. «Новые и нетрадиционные технологии в ресурсо- и энергосбережении», 28-29 сент. 2006г., Одесса - Киев: АТМ Украины, 2006.- С. 16 - 20.

[2] Воінова С.О. Технічна геронтологія і якість роботи зношеного устаткування / Матер. VI Междунар. н. практич. конф «Качество, стандартизация, контроль: теорія и практика», 26-28 сент. 2006г., Ялта. - Киев: АТМ Украины, 2006. - С.14-16.

[3] Воинова С.А. Техническая геронтология. Потенциал влияния на эффективность функционирования технических объектов / Матер. за VI Международна научна практична конференция «Найновите постижения на европейската наука-2010», 17 - 25 юни, 2010г. Том 20 «Технологии. Физическа култура и спорт».- София: «Бял ГРАД-БГ» ООД, 2010.- С. 79-84.

[4] Воінова С.О. Управління технічними об’єктами і технічна геронтологія / Щоквартальний наук.-виробн. журнал «Автоматизація технологічних і бізнес-процесів», 2011, № 7, 8.- Одеса: ОНАХТ, 2011.- С. 20-23.

[5] Воинова С.А. Место технической геронтологии в специальных дисциплинах технического вуза / Зб. тез. допов. 32-ї наук. - метод. конф. викладачів ОДАХТ “Проблеми методичного забезпечення багатоступеневої вищої освіти”, Одеса, 10-12 квітня 2001р. - Одеса: Міносвіти України, 2001. - С.46. 